\title{
ISOLASI BIOAKTIF BUNGA KARANG SEBAGAI FUNGISIDA PADA BENIH UDANG WINDU Penaeus monodon
}

\author{
Muliani*), Emma Suryati*, Arifuddin Tompo*, Andi Parenrengi* dan Rosmiati*
}

\begin{abstract}
ABSTRAK
Penelitian bertujuan mendapatkan bioaktif sponge yang efektif sebagai fungisida dalam rangka kegiatan produksi benih udang windu. Penelitian meliputi beberapa tahapan kerja yaitu: (1) Isolasi dan identifikasi jamur penyebab penyakit pada udang; (2) Penapisan dan identifikasi potensi sponge sebagai fungisida; dan (3). Isolasi dan pemurnian bioaktif sponge untuk fungisida. Berdasarkan hasil isolasi dan identifikasi terdapat empat jenis jamur pada benih udang windu yaitu: Aspergillus spp., A. fumigatus, Fusarium spp. dan F. solani yang kemudian digunakan sebagai bioindikator. Penapisan terhadap 25 ekstrak kasar sponge yang diduga potensial sebagai penghasil fungisida menemukan tiga spesies sponge yang sangat potensial yaitu Auletta sp., Clathria spp., dan Thionella cylindrica. Ekstrak kasar dari Auletta spp. menghambat pertumbuhan A. fumigatus, Clathria spp. menghambat pertumbuhan Aspergillus spp., A. fumigatus, dan Fusarium spp., sedang dari T. cylindrica menghambat pertumbuhan semua jenis jamur yang digunakan sebagai bioindikator. Daya hambat ekstrak $T$. cylindrica paling tinggi $(\mathrm{P}<0,05)$ terhadap jamur Fusarium solani, kemudian berturut-turut terhadap Aspergillus sp, Fusarium spp. dan A. fumigatus. Daya hambat ekstrak Clathria spp. tidak berbeda nyata $(\mathrm{P}>0,05)$ terhadap semua bioindikator, bahkan sama sekali tidak ada terhadap $F$. solani. Hasil fraksionasi membuktikan bahwa $T$. cylindrica aktif menghambat pertumbuhan $F$. solani $(27,20 \mathrm{~mm})$ pada fraksi air. Uji kromatografi lapis tipis menunjukkan bahwa campuran pelarut yang sesuai adalah n-buthanol-ethil asetat-air (5:4:1). Dari uji hayati diperoleh fraksi air yang aktif sebagai fungisida adalah fraksi ke $\mathrm{E}$.
\end{abstract}

\section{ABSTRACT: Isolation of sponges bioactive for fungiside of tiger shrimp Penaeus monodon fry. By: Muliani, Emma Suryati, Arifuddin Tompo, Andi Parenrengi dan Rosmiati.}

The experiment aimed to identify the efectiveness of sponges bioactive as fungicide, through a series of activities i.e (1) Isolation and identification of fungi from tiger shrimp fry; (2) Screening and identification of sponges producing fungicide; and (3) Isolation and purification of sponges fungicide. Four species of fungie (Aspergillus spp., A. fumigatus, Fusarium spp. and F. solani) isolated from tiger shrimp fry were used as bioindicator. Among 25 crude extracts of sponges tested against the bioindicator, crude extract of Auletta spp. inhibited the growth of A. fumigatus, crude extract of Clathria spp. inhibited the growth of Aspergillus spp., A. fumigatus, and Fusarium spp., and crude extract of Thionella cylindrica was a good inhibitor for all of the bioindicators. The most potent inhibition toward A. fumigatus was resulted by the crude exctract of Auletta spp. and the weakest was of T. cylindrica. The inhibition zone resulted by the crude extract of $T$. cylindrica on $F$. solani was the largest $(P<0.05)$ followed by on Aspergillus spp., A. fumigatus, and Fusarium spp. Inhibiton zone of crude extract from Clathria spp. on Aspergillus spp., A. fumigatus, and Fusarium spp. was not significantly different $(P<0.05)$. Among the three species of sponge fractionated, T. cylindrica was active inhibiting the growth of Fusarium sp (27.20 mm) on water fraction. The results of the layer chromatography test showed that n-buthanol:ethyl acetate:water (5:4:1) was suitable. Fraction E could inhibit the growth of Fusarium spp.

KEYWORDS: bioactive, sponge, fungicide, tiger shrimp.

\section{PENDAHULUAN}

Dengan meningkatnya usaha budidaya perikanan pantai yang bertujuan meningkatkan produksi, timbul beberapa kendala di dalam pengelolaan lingkungan serta kesehatan hewan yang dipelihara. Selain itu masalah penyakit yang disebabkan oleh jamur sering kali menyerang larva yang dipelihara di panti benih dan mengakibatkan kerugian yang tidak sedikit. Dari

\footnotetext{
Peneliti pada Balai Penelitian Perikanan Pantai
} 
penelitian inventarisasi telah dilaporkan jenisjenis penyakit yang sering menyerang udang windu seperti parasit protozoa (Zoothamnium, Epystilis, Vorticella), jamur (Lagenidium, Fusarium), bakteri (Vibrio harveyi, Vibrio alginoliticus), dan virus (Monodon Baculo Virus), di Sulawesi Selatan, Bali dan Jawa (Partasasmita et al., 1988 dan Lightner et al., 1989).

Penelitian penanggulangan penyakit masih terbatas pada pemakaian bahan-bahan kimia seperti formalin, malachite green serta beberapa jenis antibiotik seperti chloramfenicol, oxytetracyclin, dan prefuran (Sunarya et al., 1993). Penggunaan bahan alami masih terbatas pada saponin dan rotenon (Hadiman, 1982). Beberapa jenis sponge yang dilaporkan memiliki bioaktif antara lain sesteterpen dari Hyatella intestinalis (Karuso et al., 1989), metil steroid dari Agelas flabelliformis (Gunasekara et al., 1989), Hipospongia comunis, Spongia officinalis, Ircinia virabilis, Spongia gracilis masing-masing mengandung sesteterpen, terpenoid, variabilin dan ketosteroid (Madaio et al., 1989), avarol dari Dysidea avara (Crispino et al., 1989), dan metil steroid glikosida dan ketosteroid dari Erylus cendenfeldi dan Dyctionella insica (Cimminiello et al., 1989). Dari penelitian isolasi dan identifikasi bioaktif sponge untuk bakterisida diperoleh beberapa jenis sponge yang mampu menghambat pertumbuhan beberapa jenis bakteri penyebab penyakit pada komoditas perikanan, seperti Auletta sp., Halichondria sp. dan Callyspongia sp. di antaranya mengandung senyawa sterol, peptida dan asam fenolat (Suryati et al., 1995; Ahmad et al., 1995; dan Muliani et al., 1996 dan 1997, Muliani \& Suryati 1997).

Selain bermanfaat dalam bidang farmasi dan pengobatan pada manusia dan hewan, bioaktif sponge juga dapat digunakan untuk menanggulangi hama dan penyakit pada komoditas perikanan antara lain terhadap bakteri, jamur, dan virus yang sering menjadi masalah pada budidaya perikanan pantai.

Fungisida yang ada dewasa ini pada umum. nya merupakan senyawa organologam, pestisida dan antibiotik yang dapat terakumulasi dan persisten di alam, sehingga dikhawatirkan akan menurunkan mutu lingkungan. Untuk mengantisipasi hal tersebut perlu dicari alternatif lain dengan menggali sumber daya alam laut di antaranya mencari bioaktif sponge untuk fungi- sida yang akrab lingkungan pada budidaya perikanan pantai.

Penelitian bertujuan untuk mendapatkan jenis sponge efektif sebagai fungisida pada benih udang windu.

\section{BAHAN DAN METODE}

Penelitian meliputi beberapa tahapan kerja yaitu:

\section{Tahap 1. Isolasi dan identifikasi jamur penyebab penyakit pada benih udang}

Benih udang windu digerus dan diencerkan dengan $9 \mathrm{~mL}$ saline solution, diambil $0,1 \mathrm{~mL}$ diinokulasi pada media "Saborouth Dextrose Agar" (SDA) atau "Potato Dextrose Agar" plate (PDA), setelah itu diinkubasi selama 48 jam diisolasi dan dimurnikan berdasarkan bentuk dan warna hypa. Kemudian masing-masing diinkubasi selama tujuh hari, selanjutnya diwarnai dengan larutan "methylen blue" untuk identifikasi spesies jamur berdasarkan bentuk hypa (Hatai et al., 1979). Isolat yang diperoleh digunakan sebagai bioindikator pada penapisan bioaktif sponge untuk fungisida. Data disajikan secara deskriptif.

\section{Tahap 2. Penapisan dan identifikasi potensi sponge sebagai fungisida}

Sponge dikoleksi dariperairan Spermonde dan dikelompokkan berdasarkan bentuk dan warna untuk identifikasi spesies (Brusca \& Brusca 1990). Sponge hasil pengelompokan dimasukkan ke dalam metanol $80 \%$ atau disimpan pada suhu rendah. Penapisan sponge dilakukan dengan cara membuat ekstrak kasar sponge di dalam larutan metanol $80 \%$, kemudian dilakukan uji hayati terhadap jamur yang diisolasi dari benur windu. Ekstrak sponge yang memberikan daya hambat (terbentuk zona hambatan) terhadap bioindikator yang digunakan dilanjutkan dengan uji kuantitatif dengan menggunakan 40 mikroliter dari ekstrak kasar dengan konsentrasi $1 \mathrm{~g} / \mathrm{mL}$ setara dengan bobot segar dengan cara meneteskan di atas permukaan paper disk. Kemudian paper disk tersebut diletakkan di atas permukaan PDA yang telah diinokulasi dengan jamur, setiap cawan petri diisi paper disk sebanyak empat buah, 
selanjutnya diinkubasi selama 48 jam pada suhu $25^{\circ} \mathrm{C}$. Masing-masing ekstrak diuji dengan lima ulangan. Zona hambatan yang terbentuk pada jamur diukur diameternya satu persatu menggunakan mistar geser, kemudian dirata-ratakan. Data yang diperoleh dianalisis dengan menggunakan sidik ragam.

\section{Tahap 3. Isolasi dan pemurnian bioaktif sponge untuk fungisida}

Bioaktif sponge diisolasi dengan cara ekstraksi, fraksionasi serta pemisahan secara kromatografi kolom, lapis tipis, lapis tipis preparatif, dan kinerja tinggi (HPLC). Uji aktivitas bioaktif hasil fraksionasi dilakukan terhadap bioindikator jamur yang telah diisolasi (Tahap 2) volume isolat yang digunakan adalah 40 mikroliter dari ekstrak kasar dengan konsentrasi $1 \mathrm{~g} \mathrm{~mL}$ setara dengan bobot segar. Masing-masing isolat diuji dalam tiga ulangan. Parameter yang diukur adalah zona hambatan pada pertumbuhan jamur. Data yang diperoleh dianalisis dengan menggunakan sidik ragam. Pemurnian hasil fraksionasi dilakukan dengan kromatografi kolom menggunakan pelarut antara lain n-buthanol, ethil asetat, dan air, bioaktif hasil pemurnian diuji terhadap bioindikator jamur.

\section{HASIL DAN PEMBAHASAN}

\section{Tahap 1. Isolasi dan identifikasi jamur penyebab penyakit pada ikan/ udang}

Hasil isolasi dan identifikasi jamur pada benur udang windu yang diambil dari beberapa panti benih ditemukan ada empat jenis jamur yaitu: Aspergillus spp., A. fumigatus, Fusarium spp., dan Fusarium soloni. Hatai et al. (1979) melaporkan bahwa salah satu jenis jamur yang menyebabkan penyakit insang hitam pada udang windu adalah Fusarium spp.

Tahap 2. Penapisan dan identifikasi serta potensi sponge sebagai fungisida

Pada penelitian penapisan dan identifikasi sponge untuk fungisida diperoleh sebanyak 25 spesies (Lampiran 1). $200 \mathrm{~g}$ dari setiap jenis sponge dibuat ekstrak kasar dengan pelarut metanol 80\% kemudian diuji keaktifannya menggunakan bioindikator jamur yaitu Aspergillus spp., A. fumigatus, Fusarium spp. dan Fusarium soloni dengan volume ekstrak sebanyak 40 mikroliter dari ekstrak kasar dengan konsentrasi 1 $\mathrm{g} / \mathrm{mL}$ setara bobot segar yang digunakan. Dari hasil uji hayati tersebut diperoleh empat spesies yang mampu menghambat pertumbuhan jamur (Lampiran 1).

Hasil penapisan terhadap 25 ekstrak kasar sponge, diperoleh tiga spesies sponge yang memperlihatkan hambatan yang sangat besar yaitu Auletta spp. (warna abu-abu), Clathria spp., dan T. cilindrica. Auletta spp. (warna abu-abu) selain aktif menghambat jamur juga aktif terhadap bakteri (Ahmad et al., 1995; Suryati et al., 1995; Muliani et al., 1996). Adapun ciri dari ketiga spesies sponge yang potensial sebagai fungisida disajikan pada Gambar 1, 2, dan 3 (Ahmad et al., 1996; Amir \& Budiyanto, 1996; Barnes, 1990). Ketiga jenis sponge ini diuji lebih lanjut untuk melihat daya hambatan secara kuantitatif. Data mengenai perbedaan daya hambat dari masingmasing jenis sponge diperoleh dengan analisis sidik ragam.

Auletta spp. yang digunakan dalam penelitian ini termasuk dalam famili Axinellidae ordo Axinellida dan biasa didapatkan pada terumbu karang pada daerah perbatasan antara perairan bersuhu rendah dan tinggi. Bentuk tubuhnya seperti silinder kosong bercabang banyak dengan warna abu-abu, sampai mengarah ke biru muda. Tinggi dapat mencapai $30 \mathrm{~cm}$, spikulanya (organ berukuran sangat kecil penyusun jaringan tubuh) tidak tampak jelas dan tersusun dari silikat dioksida, protein, spongin, atau gabungan silikon dan spongin (Amir \& Bidiyanto, 1996).

Clathria sp. yang digunakan dalam penelitian ini termasuk dalam kelas Calcacera famili Microcinidae. Spikula tersusun dari kalsium karbonat dan tidak mengandung spongin. Sebagian besar bentuknya kecil-kecil dan berwarna putih keabuabuan, kuning, pink, atau hijau. Elemen kerangka berbentuk spikula triaxon dan tidak ada perbedaan antara megasklera dengan mikrosklera. Ekostosomnya seperti tonjolan bulu-bulu sikat dari subtylostyle (Amir \& Budiyanto 1996). 


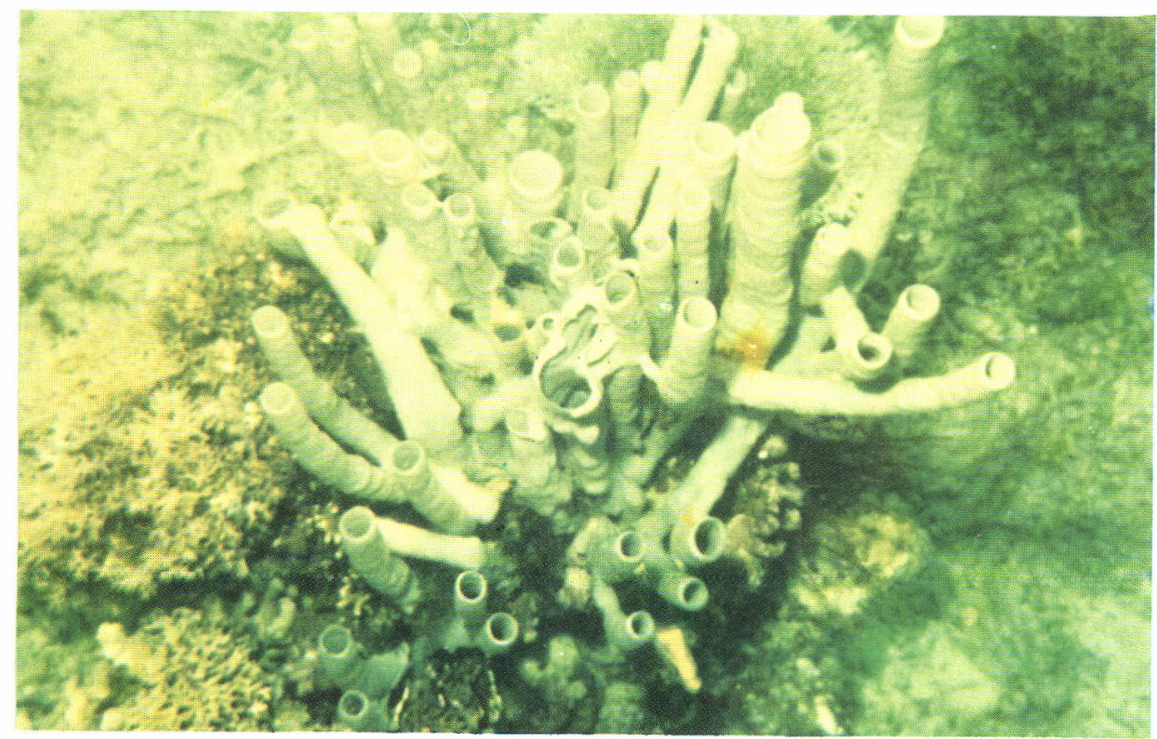

Gambar 1. Sponge Auletta spp. yang memiliki bioaktif yang dapat menghambat pertumbuhan $A$. fumigatus, dan Fusarium spp. pada benih udang windu dari panti perbenihan.

Figure 1. Auletta spp. producing bioactive which is very effective for A. fumigatus eradication from shrimp hatchery.

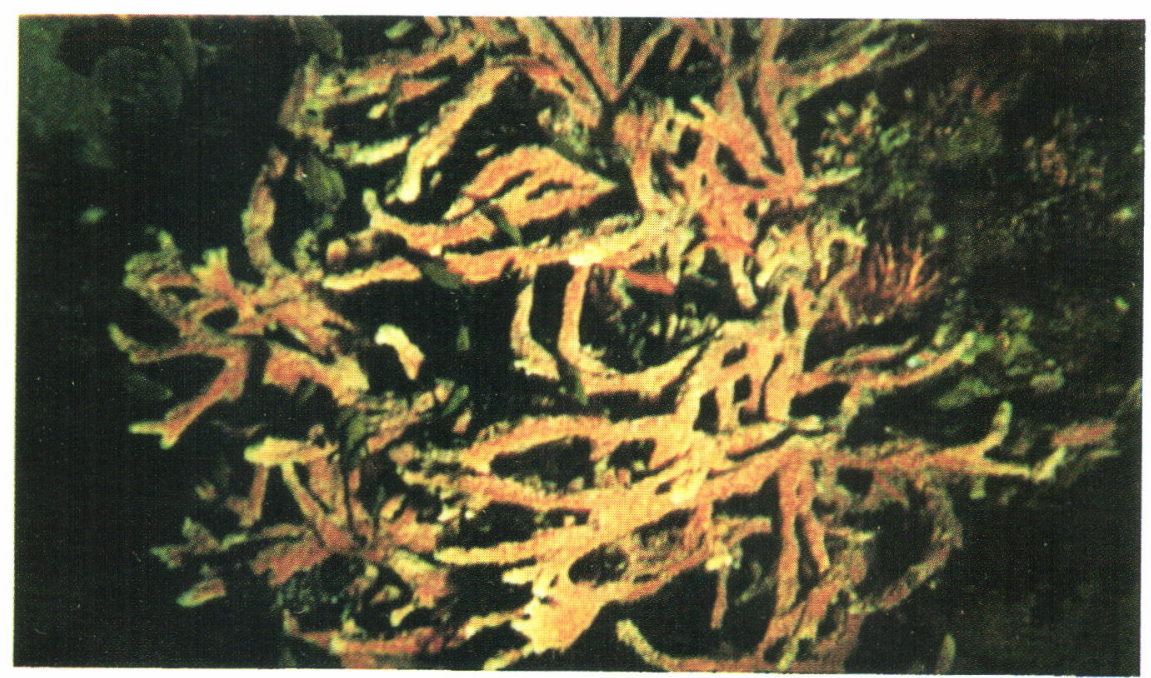

Gambar 2. Sponge Clathria spp. yang memiliki bioaktif yang dapat menghambat pertumbuhan Aspergillus spp., A. fumigatus dan Fusarium spp. pada benih udang windu dari panti perbenihan.

Figure 2. Clathria spp. producing bioactive which is very effective for Aspergillus spp., A. fumigatus, and Fusarium spp. eradication from shrimp hatchery. 


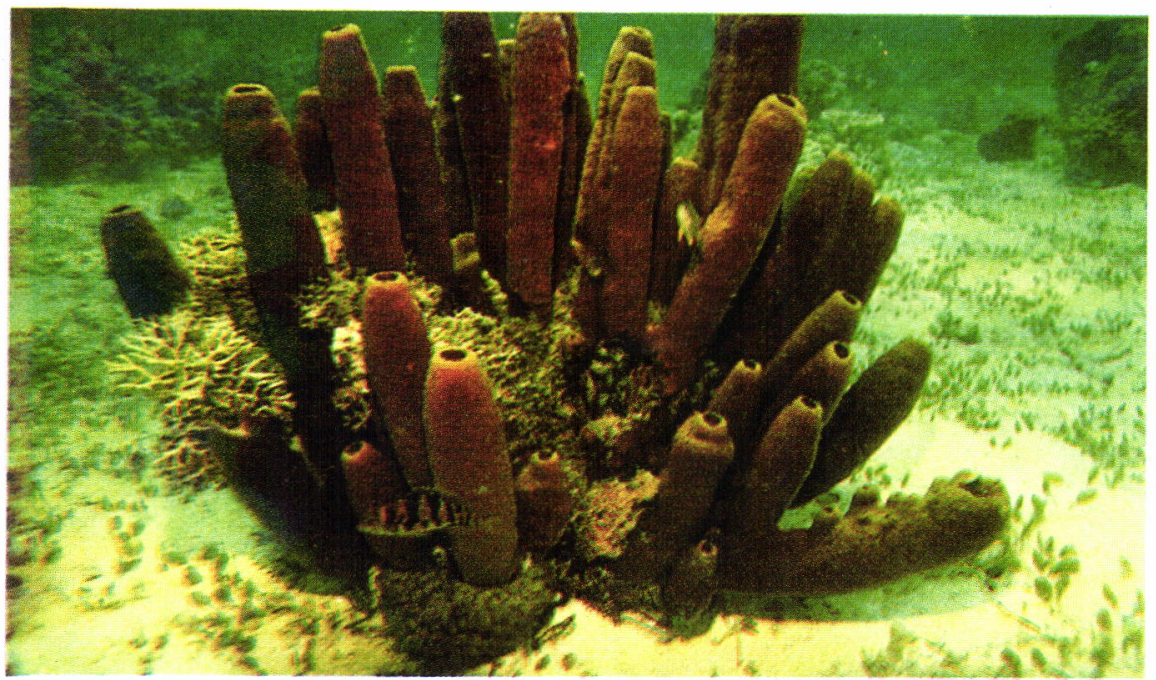

Gambar 3. Sponge Thionella cylindrica yang memiliki bioaktif yang dapat menghambat pertumbuhan Aspergillus spp., A. fumigatus, Fusarium spp., and F. solani pada benih udang windu dari panti perbenihan.

Figure 3. Thionella cylindrica producing bioactive which is very effective for Aspergillus spp., A. fumigatus, Fusarium spp., and F. solani eradication from shrimp hatchery.

T. cylindrica termasuk dalam famili Theonellidae ordo Lithisida. Warnanya agak kecoklatcoklatan, dapat mencapai panjang $70 \mathrm{~cm}$, berbentuk tabung silinder dengan percabangan umumnya terdapat pada pangkal tubuh (Amir \& Budiyanto 1996).

Hasil uji daya hambat secara kuantitatif menunjukkan bahwa Auletta spp. (warna abu-abu) mampu menghambat $A$. fumigatus dengan ratarata diameter hambatan $30,3 \pm 2,2 \mathrm{~mm}$. Selain aktif menghambat pertumbuhan jamur Auletta spp. jenis ini juga aktif menghambat pertumbuhan bakteri (Ahmad et al., 1995; Suryati et al., 1995; Muliani et al., 1996). Clathria spp. mampu menghambat Aspergillus spp., A. fumigatus, dan Fusarium spp. dengan rata-rata diameter hambatan masing-masing $24,7 \pm 2,28 \mathrm{~mm}, 27,8 \pm 3,59$ $\mathrm{mm}$, dan 25,4 $22,05 \mathrm{~mm}$, sedangkan Thionella cylindrica mampu menghambat jamur Aspergillus spp., A. fumigatus, Fusarium spp. dan F. solani, dengan rata-rata diameter hambatan masing-masing $25,9 \pm 0,05 \mathrm{~mm}, 21,3 \pm 0,04 \mathrm{~mm}$, $25,4 \pm 4,15 \mathrm{~mm}$, dan $29,1 \pm 0,05 \mathrm{~mm}$. Hasil penelitian sebelumnya menunjukkan bahwa Clathria spp. dan Thionella cylindrica tidak mampu menghambat pertumbuhan semua jenis bakteri yang dijadikan bioindikator. Hal ini menunjukkan bahwa bioaktif sponge sangat potensial sebagai fungisida selektif, di mana satu jenis sponge dapat menghambat pertumbuhan salah satu jenis jamur, tetapi tidak dapat menghambat pertumbuhan bakteri, atau bahkan hanya terhadap jamur tertentu saja. Perbedaan daya hambat bioaktif sponge terhadap jamur umumnya disebabkan karena adanya perbedaan dari golongan dan komponen senyawa kimia yang terkandung dalam sponge. Barnes et al. (1990) melaporkan bahwa bioaktif yang terkandung dalam sponge berasal dari hasil metabolisme sekunder yang bermanfaat di dalam pertahanan tubuh dari predator serta penghambat di dalam proses pencernaan secara enzimatis dalam sponge tersebut.

Hasil analisis sidik ragam terhadap perbedaan daya hambat antara Auletta spp., Clathria spp., dan Thionella spp. terhadap jamur Aspergillus fumigatus menunjukkan perbedaan yang nyata $(\mathrm{P}<0,05)$. Hasil uji BNT menunjukkan bahwa, daya hambat $T$. cylindrica, berbeda nyata dengan Aulettaspp. dan Clathria spp., sedangkan antara Auletta spp. dan Clathria spp. tidak ada perbedaan yang nyata (Gambar 4). 


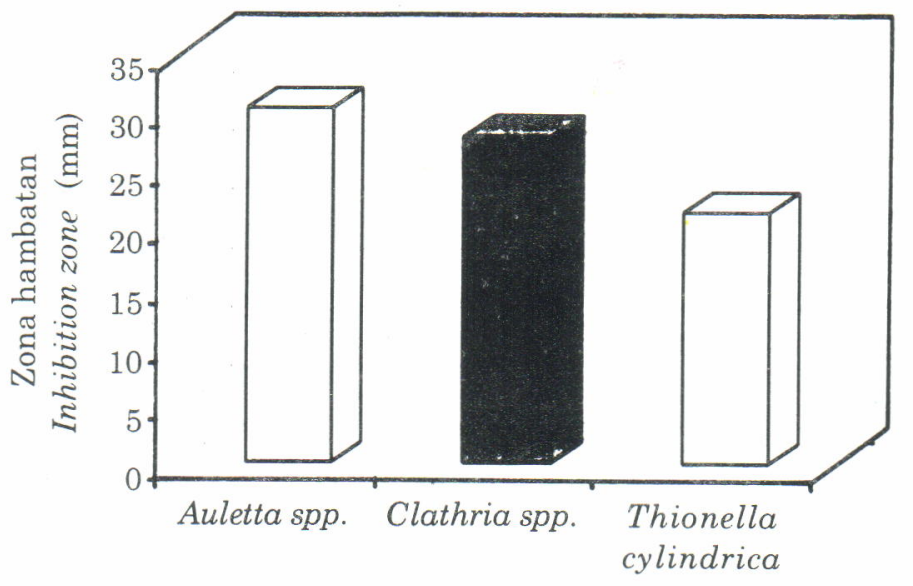

Sponges

Gambar 4. Zona hambatan Auletta spp., Clathria spp., and T. cylindrica terhadap jamur Aspergillus fumigatus.

Figure 4. Inhibition zone ( $\mathrm{mm}$ ) of sponges Auletta spp., Clathria spp., and T. cylindrica crude extracts on Aspergillus fumigatus.

Dari Gambar 4 terlihat bahwa, daya hambat Auletta spp. terhadap A. fumigatus lebih tinggi dibanding dengan Clathria spp. dan T. cylindrica. Hal ini menunjukkan bahwa Auletta spp. dan Clathria spp. dapat dijadikan fungisida selektif terhadap A. fumigatus pada udang windu.

Beberapa peneliti melaporkan adanya senyawa kimia yang spesifik di dalam sponge yang dapat dimanfaatkan untuk menghambat pertumbuhan jamur Candida spp., yang dapat dihambat oleh nukleoside pada sponge Jaspis spp. dan steroid glycosida dari sponge Erylis lendifaldi (Zabriskie et al., 1989 dan Carmely et al., 1989).

Hasil analisis sidik ragam terhadap perbedaan daya hambat $T$. cylindrica terhadap jamur Aspergillus fumigatus, Aspergillus spp., Fusarium solani, dan Fusarium spp. memperlihatkan perbedaan yang nyata $(\mathrm{P}<0,05)($ Tabel 1$)$. Dari tabel tersebut terlihat bahwa daya hambat $T$. cylindrica terhadap Fusarium spp., tidak berbeda nyata dengan Aspergillus spp., tetapi keduanya berbeda nyata dengan Fusarium soloni dan $A$. fumigatus, begitu pula daya hambat $T$. cylindrica terhadap A. fumigatus berbeda nyata dengan Fusarium spp. dan Fusarium soloni. Perbedaan aktivitas dari ekstrak sponge terhadap beberapa spesies jamur sangat ditentukan oleh struktur morfologi jamur serta komponen senyawa kimia pada masing-masing jamur yang berinteraksi dengan bioaktif sponge, antara lain menghambat pertumbuhan hypa serta memotong siklus reproduksi dari jamur. Salle (1961) melaporkan bahwa fungisida yang mengandung asam fenolat umumnya dapat menghambat pertumbuhan hypa jamur serta proses reproduksinya.

Hasil analisis sidik ragam daya hambat Clathria spp. terhadap jamur disajikan pada Gambar 5. Dari gambar tersebut terlihat bahwa, daya hambat Clathria spp. terhadap jamur Aspergillus spp., A. fumigatus dan Fusarium spp. tidak memperlihatkan perbedaan yang nyata $(\mathrm{P}>0,05)$.

Hasil penapisan terhadap bakteri Clathria spp. tidak memberikan hambatan terhadap semua bakteri yang dicobakan (Acinetobacter spp., Aeromonas spp., Enterobacteriaceae, Pseudomonas spp., dan Vibrio spp.) yang dijadikan bioindikator (Ahmad et al., 1995; Suryati et al., 1995). Berdasarkan hal tersebut maka dapat dikatakan bahwa bioaktif yang terkandung dalam Clathria spp. (Gambar 2) dapat dijadikan fungisida selektif pada komoditas perikanan dengan membuat sintesisnya. 
Tabel 1. Rata-rata daya hambat $(\mathrm{mm})$ Thionella cylindrica terhadap beberapa jenis jamur.

Table 1. Average inhibition zone $(\mathrm{mm})$ of fungicide extracted from sponge T. cylindrica on fungi.

\begin{tabular}{lc}
\hline Jenis Jamur (Fungi) & Thionella cylindrica \\
\hline Aspergillus spp. & $25.9^{\mathrm{b}}$ \\
Aspergillus fumigatus & $21.3^{\mathrm{a}}$ \\
Fusarium spp. & $25.4^{\mathrm{b}}$ \\
Fusarium solani & $29.1^{\mathrm{c}}$
\end{tabular}
Keterangan (Note): Nilai yang diikuti huruf yang sama pada setiap baris menunjukkan perbedaan yang tidak nyata (Values followed by similar letter in each line are not significantly different $)(\mathrm{P}>0.05)$

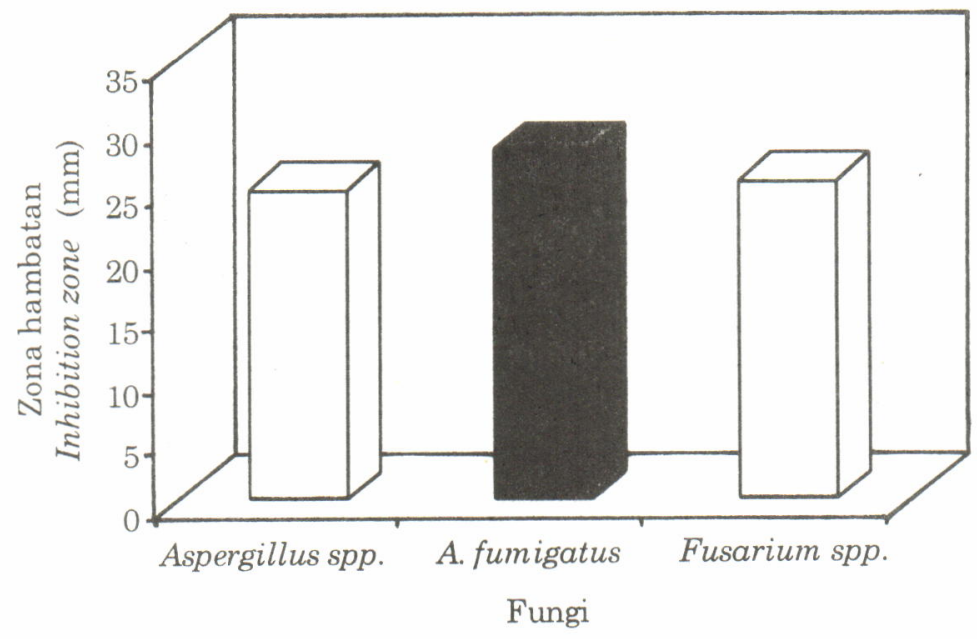

Gambar 5. Rata-rata daya hambat (mm) Clathria spp. terhadap jamur Aspergillus spp., A. fumigatus dan Fusarium spp.

Figure 5. The capability of bioactive extracted from Clathria spp. to inhibit the growth of Aspergillus spp., A. fumigatus dan Fusarium spp.

\section{Tahap 3. Isolasi dan pemurnian bioaktif sponge untuk fungisida}

Ketiga jenis sponge yang mampu menghambat salah satu atau semua jenis jamur yang digunakan sebagai bioindikator (pada tahap 2), kemudian difraksinasi dan dilakukan pemisahan secara kromatografi kolom, lapis tipis, dan lapis tipis preparatif. Dari hasil fraksionasi ketiga jenis sponge (Auletta spp., Clathria spp. dan Thionella cylindrica) ternyata hanya Thionella cylindrica yang memperlihatkan daya hambat terhadap salah satu jenis jamur yang dijadikan sebagai bioindikator yaitu terhadap jamur Fusarium solani dengan daya hambat $27,20 \mathrm{~mm}$ (Tabel 2) pada dosis 40 mikroliter dari ekstrak $1 \mathrm{~g} / \mathrm{mL}$ setara bobot segar. Berbeda dengan hasil uji hambatan terhadap bakteri, di mana terdapat tiga jenis sponge yang telah difraksinasi mampu menghambat pertumbuhan bakteri (Ahmad et al., 1995; Suryati et al., 1995). Hal ini kemungkinan disebabkan oleh efek sinergis dari bioaktif yang terkandung pada sponge Clathria spp. dan Auletta spp. yang saling menguatkan, sehingga 
dengan pemisahan secara fraksinasi dapat mengurangi/menghilangkan aktivitas dari bioaktif. nya.

Pemurnian selanjutnya dilakukan dengan kromatografi kolom terbuka. Berdasarkan hasil pengujian menggunakan kromatografi lapis tipis, campuran pelarut yang sesuai adalah $n$-buthanol. ethil asetat-air $(5: 4: 1)$, hasilnya diperoleh enam fraksi. Uji hayati selanjutnya diperoleh fraksi yang aktif yaitu pada fraksi $\mathrm{E}$ (Tabel 3).

Hasil pemisahan fraksi $E$ yaitu pada penam. pungan ke-46 sampai ke-53 menunjukkan satu noda pada Kromatografi Lapis Tipis (KLT). Hal ini berarti bahwa dalam fraksi ini hanya terdapat satu komponen senyawa kimia yang aktif meng. hambat pertumbuhan jamur yang digunakan sebagai bioindikator. Meskipun demikian bioaktif yang terkandung dalam sponge tersebut belum dapat diketahui, sehingga perlu dilakukan identifikasi lebih lanjut. Hasil uji hambatan senyawa yang terkandung dalam $T$. cylindrica yang telah dipisahkan secara kromatografi lapis tipis menunjukkan adanya peningkatan dari ekstrak metanol dan hasil fraksinasinya. Hal ini disebab. kan adanya proses pemurnian dari senyawa yang terkandung dalam sponge tersebut.

Jika dilihat dari daya hambat mulai dari ekstrak kasar, hasil fraksionasi, dan hasil pemurnian dengan kromatografi kolom terbuka, terlihat bahwa $T$. cylindrica mempunyai prospek sebagai fungisida terhadap jamur pada udang windu, karena mampu menghambat pertumbuhan keempat jenis jamur yang digunakan (Asper.

Tabel 2. Zona hambatan dari hasil fraksinasi Thionella cylindrica dengan bioindikator jamur Fusarium solani.

Table 2. Inhibition zone of Thionella cylindrica fractions on Fusarium solani.

\begin{tabular}{lc}
\hline \multicolumn{1}{c}{ Fraksi aktif (Active fraction) } & $\begin{array}{c}\text { Zona hambatan } \\
\text { (Inhibition zone) } \\
\text { (mm) }\end{array}$ \\
\hline 1. Ekstrak kasar (Crude exstract) & $30.21 \pm 0.05$ \\
2. Fraksi heksan (Hexan fraction) & - \\
3. Fraksi asam ethil asetat (Acid ethyl acetate fraction) & - \\
4. Fraksi ethil asetat netral (Neutral ethyl acetate fraction) & - \\
5. Fraksi air (Water fraction) & $27.20 \pm 0.05$ \\
\hline Keterangan (Note):(.) tidak ada zona hambatan (no inhibition zone)
\end{tabular}

Tabel 3. Zona hambatan hasil pemisahan dengan kromatografi kolom terbuka dari Thionella cylindrica dengan bioindikator jamur Fusarium solani.

Table 3. Inhibition zone of water fraction of bioactive extracted from Thionella cylindrica on Fusarium solani.

\begin{tabular}{lc}
\hline Fraksi Aktif (Active fraction) & $\begin{array}{c}\text { Zona Hambatan (Inhibition zone) } \\
(\mathbf{m m})\end{array}$ \\
\hline Fraksi air (Water fraction) & $27,20 \pm 0,05-$ overlap \\
1. Fraksi (Fraction) A (1-2) & - \\
2. Fraksi (Fraction) B (3) & - \\
3. Fraksi (Fraction) C (4-14) & - \\
4. Fraksi (Fraction) D (15-45) & $31,40 \pm 0,05$ \\
5. Fraksi (Fraction) E (46-53) & $\cdot$ \\
6. Fraksi (Fraction) F (54-87) &
\end{tabular}

Keterangan (Note): (.) tidak ada hambatan (No inhibition) 
gillus spp., A. fumigatus, Fusarium spp. dan $F$. solani). Secara umum bioaktif yang terkandung dalam sponge mudah terurai dalam air sehingga penggunaannya aman terhadap lingkungan, akan tetapi zat bioaktif yang terkandung di dalamnya sangat kecil (Carmely et al., 1989; Cimminiello et al., 1989). Suryati et al. (1997) mengemukakan bahwa bioaktif yang terkandung dalam sponge berkisar antara $0,01-0,1 \%$ dari bobot segar sehingga sulit untuk mengharapkan dari alam. Oleh karena itu perlu dilakukan kemungkinan usaha budidaya sponge yang potensial sebagai fungisida dan pembuatan sintesis dari bioaktif sponge tersebut.

\section{KESIMPULAN}

1. Jamur yang menyerang benih udang windu di panti benih adalah Aspergillus spp., $A$. fumigatus, Fusarium spp. dan F. solani.

2. Terdapat tiga spesies sponge yang ekstrak kasarnya aktif menghambat pertumbuhan jamur yang menyerang benih udang windu secara spesifik yaitu: Auletta spp., Clathria spp., dan T. cylindrica.

3. Dari hasil pemurnian ketiga jenis sponge didapatkan bahwa hanya satu fraksi (E) dari enam fraksi air dari $T$. cylindrica dan yang aktif menghambat pertumbuhan jamur Asper. gillus spp., A. fumigatus, Fusarium spp. dan $F$. solani pada benih udang windu.

4. T. cylindrica menghasilkan bioaktif yang sangat potensial untuk penanggulangan penyakit jamur Aspergillus spp., A. fumigatus, Fusarium spp. dan $F$. solani pada benih udang windu.

\section{UCAPAN TERIMA KASIH}

Diucapkan terima kasih kepada Nurbaya, Nurjanna, Indo Lette dan Rifka Pasande staf teknisi Laboratorium Hama dan Penyakit dan Laboratorium Plankton, Balai Penelitian Perikanan Pantai, Maros.

\section{DAFTAR PUSTAKA}

Ahmad, T., E. Suryati dan Muliani. 1995. Screening sponges for bactericide to be used in shrimp culture. Indonesian Fisheries Research Journal I(1): $1-10$
Ahmad, T dan E. Suryati. 1996. Spons sebagai sumber bakterisida alami. Majalah Trubus Edisi 318 th XXVII. 79-81.

Amir, I. dan A. Budiyanto. 1996. Mengenal spons laut (Demospongiae) secara umum. Oseana . Vol 21(2); $15 \cdot 31$

Barnes, R.D. 1990. Invertebrata zoologi. Fourth Ed. Holt Saunders International Edition

Brusca, R.C and G.J. Brusca. 1990. Invertebrates. Sinauer Associated, Inc.,Mass. USA 922 p.

Carmely, S., M. Roll, Y. Loya, and Y. Kashman. 1989. The structure of Eryloside A, a new antitumor and antifungal 4-methylated steroidal glycoside from the sponge Erylus lendenfeldi. J. Nat. Products 52(1):167-170.

Cimminiello, P., Ernesto, F. Silvana, M. and Alvinso M. 1989. A Novel conyugated keto-steroid from the marine sponge Dyctionella incisa. J. of Natural Product.52(6):1331-1333.

Crispino, A., Deguillo, S De Rosa and G. Strazullo. 1989. A new bioactive derivation of avarol from the marine sponge Dysidea avara. J. of Natural Product. 52(6):646-648.

Gunasekara, S.P., S. Cramck and R. Longlei. 1989. Immunosuppresive compounds from a deep water marine sponge, Agelas flabel-liformis. J. of Natural Product 52(4):757-761.

Hadiman. 1982. Zat bioaktive ex tanaman untuk kesejahteraan manusia. Bahan seminar intern Lab Kimia Tanam. UNPAD. Unpablished.

Hatai, K. and S. Egusa. 1979. Studi on the pathogenic fungus assosiated with black gill desease of Kuruma prawn, Penaeus japonicus II. Some of the Note on the BG-Fusarium.

Karuso, P., R.C. Cambic and B.F. Bowden. 1989. Chemisty of sponges VI Scalarane sestes-terpenes from Hyatella intestinalis. J. of Natural Product 52(2):289-293.

Lightner, D.V.. T.A. Bell, R.M. Redman, L.L. Mohley, J.M. Natividad, A. Rukyani, and A. Poernomo. 1992. A review of some major disease of economic significant on penaeid prawns/shrimp of the Americans and Indo-pacific. p: 57-80. In Shariff, I. N., R.P. Subasinghe, and R.J. Arthur (Eds.), Diseases in Asian Aquaculture. Fish Health Sect., Asian Fisheries Society, Manila. Philippines.

Madaio, A., V. Picciali and D. Sica. 1989. New polyhydroxysterols from the dictyoceratid sponges Hippospongia communis, Spongianella gracillis. J. of Natural Product 52(5): 952-961. 
Muliani, E. Suryati, dan T. Ahmad. 1996. Peluang pemanfaatan bioaktif sponge sebagai bakterisida. Makalah disampaikan pada "Temu Ilmiah Nasional Bidang Veteriner di Bogor pada taggal 12-13 Maret 1996. 9 hal.

Muliani dan E. Suryati. 1997. Efektivitas penggunaan bioaktif sponge untuk penanggulangan bakteri Aeromonas sp. pada ikan bandeng. Prosiding Simposium Perikanan Indonesia II (in press). 13 hal

Muliani, E. Suryati, dan T. Ahmad. 1997. Efektivitas penggunaan bioaktif sponge untuk penanggulangan bakteri Vibrio sp. pada udang windu. Jurnal Penelitian Perikanan Indonesia (In press). $9 \mathrm{Hal}$

Partasasmita, S., M,I, Madeali, dan A. Tompo. 1988. Inventarisasi parasit dan penyakit udang windu (Penaeus monodon) di panti benih dan tambak di Jawa dan Bali. J. Penel. Budidaya Pantai 4(1):65. 75

Salle, A.J. 1961. Fundamental principle of bacteriologi. Mc Graw Hill Book. Company Inc., London. $479 \mathrm{pp}$.
Sunarya, Kukuh. Santosa dan Mufidah. 1996. Peng. amatan residu antibiotic (oxytetracyclin) pada udang tambak. Prosiding Simposium Perikanan Indonesia I Buku II. Brdang Budidaya Perikanan. Badan Penelitian dan Pengembangan Pertanian. Hal 295-298.

Suryati, E., Muliani dan T. Ahmad. 1995. Penapisan bioaktif spons untuk bakterisida dalam bidang perikanan. Prosiding Seminar Nasional Pengelolaan Terumbu Karang Jakarta. Hal 164-168.

Suryati, E., T. Ahmad, dan Muliani. 1997. Analisis bioaktif bunga karang Auletta sp. yang aktif terhadap bakteri Vibrio sp. pada udang. Makalah disajikan pada Seminar Nasional Hasil Penelitian dalam Bidang Farmasi. Dalam Rangka Peringatan 50 Tahun Pendidikan Farmasi ITB. Tanggal 5-6 September 1997. Di Bandung. 10 hal.

Zabriskie, T.M and C.M. Ireland. 1989. The isolation and structur of modified bioactive nucleosides from Jaspis Johnstoni. J. Of Natural Product 52(6): 1353-1357 
Lampiran 1. Potensi ekstrak kasar beberapa spesies sponge terhadap jamur yang biasa menyerang benih udang windu Penaeus monodon.

Appendix 1. Potency of fungicide contained in crude extract of different species of sponges.

\begin{tabular}{|c|c|c|c|c|}
\hline \multirow{2}{*}{ Jenis Sponge (Sponges) } & \multicolumn{4}{|c|}{ Jenis jamur (Fungi) } \\
\hline & $\begin{array}{l}\text { Aspergillus } \\
\text { fumigatus }\end{array}$ & Fusarium solani & Aspergillus spp. & Fusarium spp. \\
\hline Asterospus sarasinorum & $\cdot$ & - & - & - \\
\hline Auletta spp. & +++ & - & - & . \\
\hline Callyspongia spp. & $\cdot$ & - & - & . \\
\hline Callyspongia pseudoreticulata & $\cdot$ & - & - & - \\
\hline Cinachyra & $\cdot$ & - & - & - \\
\hline Clathria spp. & +++ & - & +++ & ++++ \\
\hline Clathria reinwardi & $\cdot$ & - & : & $\cdot$ \\
\hline Conyspongia spp. & $\cdot$ & $\cdot$ & - & $\cdot$ \\
\hline Cribochalina & - & - & - & - \\
\hline Desmosposma & $\cdot$ & - & - & - \\
\hline Dysidea spp. & $\cdot$ & $\cdot$ & $:$ & - \\
\hline Echynodictium & $\cdot$ & - & - & - \\
\hline Gelliodes & & & - & - \\
\hline Halichondria cartilagena & - & $\cdot$ & - & - \\
\hline Haliclona spp. & $\cdot$ & - & - & - \\
\hline Jaspis spp. & + & + & + & + \\
\hline Pericarax & - & - & - & - \\
\hline Phokelia flabelata & $\cdot$ & - & - & $\cdot$ \\
\hline Phylospongia & $\cdot$ & $\cdot$ & $\cdot$ & - \\
\hline Plakortis nigra & - & . & - & - \\
\hline Strongilacidone & - & - & - & - \\
\hline Thalyasias vulpina & - & - & $\cdot$ & $\cdot$ \\
\hline Theonella cilindrica & ++++ & ++++ & ++++ & ++++ \\
\hline Unidentified sponge & $\cdot$ & $\cdot$ & - & - \\
\hline Xestospongia & - & - & - & $\cdot$ \\
\hline
\end{tabular}

Keterangan (Note): (-) tidak ada hambatan (no inhibiton)

$(+)$ hambatan lemah (weak inhibition)

$(+++)$ hambatan kuat (strong inhibition) 